Of base-load generator sets, he said that these will undoubtedly become standard practice in the Navy, possessing as they do several advantages over diesel sets, to which they are preferred above $350 \mathrm{~kW}$. Mr. Pope then gave details of a 1,000-kW. base-load generator set and of a $500-\mathrm{kW}$. set.

On merchant marine applications, Mr. Pope remarked that engines for this purpose operate their whole life at full power, and, due to the cost of running, only one experimental set has so far been built. He gave figures, however, to prove that maintenance costs are much lower than those for diesel engines, and possibly than those of steam turbines. There is, he said, a certain amount of interest in emergency gas turbine generator sets for the merchant marine. One such machine has been developed; it was first run only 21 months after the initiation of the project, and was delivered after only 26 months.

"Air Development" was the theme of an address by Dr. A. W. Morley, head of Forward Projects Investigations Department, Messrs. D. Napier and Sons, Ltd. Dr. Morley traced the development of the gas turbine engine, dating from Dr. A. A. Griffiths (1926), who applied Prof. Frankel's theory of circulation, to the turbo-prop and jet engines which are known to-day. The piston-engine transport, he said, belongs to the past, and he showed a short film of the conversion of the piston-engine transport to the turbo-prop transport (Convair 340). 'The reasons for the conversion became evident as the lecture developed ; namely, it provided a saving of weight and an increase of power, so that the cruising speed went up as well as the pay-load. This conversion utilized the Eland turbo-prop engine, and Dr. Morley justified the title of his lecture by describing in detail the principles and development of the above engine, including the control system, fuel metering system and torque meter. He also dealt with some of its safety aspects, detailing the maximum torquemeter, and overspeed governor, stressing the fact that the ideal design is such that if one part fails something else comes into play.

Dr. Morley then showed how the introduction of new conceptions brings about new machines, as for example in the Fairey Rotodyne (rotor, 90 ft. diameter), Rolls-Royce "Flying Bedstead" and in helicopter development.

Applications to the motor vehicle were dealt with by Dr. J. H. Weaving, chief research engineer, Austin Motor Co., who described the main steps in development, with slides showing the calculations and results represented in graphical form.

The importance of the heat exchanger was emphasized, and it was shown that there is no point in having high compression ratios if a heat exchanger is used. Dr. Weaving compared the efficiencies of the gas turbine with heat exchanger, petrol and diesel engines at full load; it is possible to achieve efficiencies with gas turbines comparable with the diesel engine if a thermal ratio of 0.9 is used, and comparable with the petrol engine if a thermal ratio of 0.7 is used.

Dr. Weaving stated that research is continuing on rigs to improvo the efficiency of individual components. A centrifugal compressor has been on test, and axial compressors of single, two and three stages have been tried. A two-stage compressor giving ratios of 4 to 1 and 6 to 1 without overstressing has been used, and a three-stage compressor is now in service. Research into the design of burner and combustion chamber is being carried out by J. Lucas and Co., Ltd.

Dr. Weaving foreshadowed great developments in the regenerative types of heat exchangers, and concluded his address with illustrations of the result of researches in Great Britain, the United States and on the Continent. The installation of the Austin turbine in the "Princess" saloon was shown, also the G.T. 302 "Whirlfire" and its novel installation with twin-disk regenerative heat-exchanger as fitted in the General Motors "Firebird".

\section{SUMMER SCHOOL IN PHYSICS IN THE UNIVERSITY OF MEXICO}

IST summer the University of Mexico held, for 1 the first time, a summer school in physics. The subject on this occasion was theoretical nuclear physics, and the course extended from July 9 until the end of August. The twenty-eight members of the school were mostly graduate students or senior staff in theoretical physics, but also included some experimental physicists. Apart from members of the University of Mexico there were visitors from the Argentine (2), Brazil (3), Cuba (1), Britain (1), France (2), Germany (1), India (1) and the United States (9).

Unesco provided for the travelling expenses of some of the members, others had grants from their own national institutions, and in addition a good deal of local expenditure was borne by the University of Mexico.

The meetings, which were conducted in English, were held in the Physics Department of the University (director, Prof. C. Graef Fernandez) and the programme was designed and arranged by Dr. M. Moshinsky, professor of theoretical physics.

The idea of such a summer school bear's some relation (and no doubt has received some inspiration) from the successful summer schools that have become regular institutions in Les Houches (France) and Varenna (Italy); but the Mexican Summer School differed from these older institutions by being rather more specialized. The five lecture courses provided all dealt with parts of nuclear theory; their subjects were: collective motions in nuclei (M. Moshinsky); theory of nuclear reactions (R. G. Thomas) ; electromagnetic reactions with nuclei (J. S. Levinger); the nuclear shell model (B. Stech); and nuclear forces (R. E. Peierls). Thus they covered specialized and well-defined sections of the subject, and with about, twenty-four lectures in each course it was possible to present each topic in fair detail. The lectures were given on three mornings and two afternoons each week. In addition, there was a weekly seminar in which the topics ranged rather more widely, and by request of the members of the School a short series of lectures by Prof. Graef Fernandez on general relativity.

One of the obvious functions of such a course was to give some inspiration and encouragement to the young, but growing, group of theoretical research workers at the University of Mexico, and one had the impression that the members of this group appreciated the opportunity of taking part in a live discussion of modern topies from a variety of points of view. 'They took part in the lectures and discussions with great enthusiasm, in spite of the language difficulty, which must have demanded of some of them as great or greater effort than the 
technical difficulties of the subject. The meetings also met with an enthusiastic response from the experimentalists associated with the new nuclear physics laboratory, and both in seminars and outside the lecture rooms there were many occasions when one heard of the fine work done on the Van de Graaff set of the laboratory, and discussed the relations of these results with the theoretical principles that were the main subject of the course.

For the foreign members of the Summer School it was a most stimulating experience to be in Mexico, both because it is always interesting to become acquainted with a new and vigorous research school, and also because they had the chance to see around them so much of beauty and interest. The new University City of Mexico is world-famous for the breath-taking beauty of its buildings and its setting, and there was time enough to see this as a particular example of the achievements of Mexican architecture, which is without comparison in its imaginative use of form and colour, and in the unique way in which it exploits modern building techniques and modern trends, while it remains firmly based on old traditions in art and an impressive sense of continuity of æsthetic values.

For the foreign members there was indeed so much to see outside the Science Institute, and outside Mexico City, that it is a tribute to the programme of the Summer School and to the sense of duty of its members that sight-seeing trips and archæological excursions were normally confined to week-ends or postponed until after the end of the course.

In principle, one might argue that surnmer schools should not be held in places so attractive as Mexico, and which offer so many alternative interests, or that they should not be held at the sponsoring University, where the local staff have their normal business to attend to. But in this case there was no sign that either of these factors was allowed to divert attention from the activities of the School.

A similar Summer School for 1957 is now under discussion and the subject is likely to be experimental nuclear physics. If the University of Mexico, and the members of the physics staff in particular, are willing to continue to carry the burden involved in the organization of a summor school, and of the generous and friendly hospitality which was pro. vided, the School will undoubtodly establish itself as an important feature in modern physics, which can provide another forum for serious discussion and a focus for the interests of physicists in Latin America.

R. E. PEIERLS

\section{MYXOMATOSIS IN AUSTRALIA}

$\mathrm{O}$ September 18 the Commonwealth Scientific and Industrial Research Organization of Australia held a conference in Melbourne to plan the country's myxomatosis campaign for the season.

The conference included representatives of the Organization, the State Departments of Agriculture and of Lands, the Commonwealth Department of Commerce and Agriculture, the Graziers' Federal Council, the Australian Wool and Meat Producers' Federation, the Australian Primary Producers' Union, Commonwealth Serum Laboratories, the Walter and Eliza Hall Institute for Medical Research, and the Australian National University. Sir Ian Clunies Ross was chairman.
Reports from all the Australian States indicated that rabbit populations are extremely low. Myxo. matosis has been largely responsible for the reduction in rabbit numbers, but other factors have also contributed; the widespread and organized use of the poison ' 1080 ' has been particularly important in Tasmania and Western Australia. Climatic conditions, too, and especially very heavy rainfall, have adversely affected rabbit breeding.

In Tasmania poisoning with ' 1080 ' has been most successful. Rabbit numbers have been reduced to an extent which compares favourably with results achieved by myxomatosis in the eastern States.

Prof. F. Fenner, of the Australian National University, reported on his examination of more than 150 strains of myxomatosis virus, including strains from Europe and America.

In Australia, strains of the virus with reduced virulence appeared in the field soon after the initial release of myxomatosis in 1950. These less-virulent strains have become dominant.

In Europe the less-virulent strains did not appear as rapidly but they are now the dominant strains there also.

The conference recommended that further largescale inoculations with the standard (high-virulence) strain of the virus should be carried out during the coming season to prolong the period of effective use of myxomatosis by allowing fewer rabbits to survive and breod.

If existing low-virulent field strains are allowed to develop without some competition from the standard strain of the disease there will be a much bigger reservoir of survivors to provide genetically resistant progeny.

A high incidence of myxomatosis in the coming spring and summer is predicted. To take maximum advantage of these favourable conditions, a campaign for the general release of the standard (high virulence) strain of the virus has just begun.

Experiments aimed at introducing the 'French' strain of the virus indicated that it did not survive in competition with the existing dominant field strain of low virulence. A warning was given against further introduction of the 'French' strain. It appears that this strain has given rise to much less virulent forms of the virus.

Experiments undertaken by Dr. I. D. Marshall, of the Australian National University, and Dr. W. R. Sobey, of the C.S.I.R.O. Animal Genetics Section, have confirmed that rabbits can inherit some degree of resistance to myxomatosis. Observations in the field have indicated that rabbits are, in fact, inheriting resistance to the disoase, but further investigations will be necessary before the degree of this inheritance can be assessed.

The conforence was told that it was believed that the European rabbit flea was a major factor in the spread of myxomatosis in the United Kingdom. The Australian Agricultural Council agreed at its meeting in July 1956 to a recommendation that the Europoan rabbit flea be used for myxomatosis experiments in Australia. Tho conference agreed that such experiments would be valuablo, subject to tests to confirm that the floa is harmless to Australian fauna.

'The conference urged all landholders to use poison ' 1080 ' and all other effective methods aftor the current myxomatosis season ends. Advantage should be taken of low rabbit numbers to kill off all survivors. The aim must be to eradicate the rabbit from Australia. 